\title{
Mężczyźni z niepełnosprawnością fizyczną jako klienci agencji towarzyskich. Perspektywa pracownic seksualnych
}

\section{Izabela Ślęzak}

Uniwersytet Łódzki

\begin{abstract}
Choć w ostatnich latach naukowcy coraz częściej poruszaja w badaniach empirycznych temat seksualności osób niepetnosprawnych, potoczna wiedza na ten temat pozostaje fragmentaryczna oraz przepetniona stereotypami. Sposoby zaspokajania przez osoby niepetnosprawne potrzeb w tym zakresie objęte sa tabu, szczególnie, jeśli wiąża się z innymi stabuizowanymi sferami, np. komercyjnymi ustugami seksualnymi. Tymczasem osoby niepetnosprawne stanowia jedna z kategorii klientów odwiedzajacych pracowników seksualnych. W rezultacie mamy do czynienia ze specyficzna sytuacja, w której osoby spotecznie spychane na margines (pracownicy seksualni) spotykaja się z niepetnosprawnymi klientami, którzy nie tylko sa spotecznie wykluczani, ale także w powszechnym rozumieniu pozbawieni potrzeb seksualnych. Artykut przedstawia perspektywę kobiet świadczących usługi seksualne w agencjach towarzyskich, które spotkaty się z niepetnosprawnymi klientami. Prezentuje sposób, w jaki postrzegaty one potrzeby seksualne u tej kategorii mężczyzn oraz jak definiowaty swoja role w ich zaspokojeniu. Przedstawia także sposoby postrzegania przez pracownice seksualne ciała niepetnosprawnych mężczyzn, co przekładało się na gotowość przyjęcia ich w roli klientów. Dane empiryczne będace podstawa artykutu pochodza z wywiadów swobodnych z pracownicami agencji towarzyskich przeprowadzonych $w$ ramach projektu dotyczacego sytuacji pracy kobiet $w$ agencjach. Zostaty one poddane analizie za pomoca procedur analitycznych metodologii teorii ugruntowanej.
\end{abstract}

Słowa kluczowe: agencje towarzyskie, praca seksualna, prostytucja, niepełnosprawni mężczyźni, potrzeby seksualne

\section{Wstęp}

Temat seksualności osób z różnego rodzaju niepełnosprawnościami, po latach niedostrzegania i unieważniania w dyskursie naukowym, w ostatnim czasie jest w nim coraz wyraźniej obecny. Ze względu na interdyscyplinarny charakter tego zagadnienia, stanowi ono obszar zainteresowania badaczy oraz praktyków reprezentujących różne obszary i dziedziny nauki - od medycyny i seksuologii po pedagogikę czy socjologię. Każda z tych perspektyw, akcentując nieco inne wątki, zwraca jednocześnie uwagę na potrzeby i braki w zakresie edukacji, terapii, a także świadomości społecznej (również wśród profesjonalistów zajmujących się rehabilitacją osób niepełnosprawnych), dotyczącej sfery potrzeb seksualnych i życia intymnego osób z różnymi dysfunkcjami.

Seksuologowie zauważają, że poczucie satysfakcji w sferze seksualnej jest ważnym elementem składowym oceny jakości życia (Izdebski 2006: 75) i wpływa na całokształt rozwoju jednostki, co nabiera szczególnego znaczenia w przypadku osób niepełnosprawnych. Jak zauważa socjolog Antonina Ostrowska (2007: 13), satysfakcjonujące życie intymne w przypadku wielu osób niepełnosprawnych ma być może więcej pozytywnych konsekwencji niż dla ogółu osób aktywnych seksualnie. W tym kontekście szczególnie ważne jest bowiem nie tylko bycie spełnionym w związku, ale będące tego 
pochodną poczucie osoby niepełnosprawnej, że jest akceptowana (a także, że akceptowane jest jej ciało). Pozytywna samoocena, która wiąże się z udanym życiem seksualnym, może przekładać się na szybsze przystosowanie do codzienności z niepełnosprawnością i twórcze funkcjonowanie w różnych rolach społecznych (Ostrowska 2007: 13).

Należy jednak zaznaczyć, że życie intymne osób niepełnosprawnych powinno być postrzegane nie tylko z perspektywy korzyści dla przebiegu rehabilitacji społecznej, ale jako niezbywalne prawo do ekspresji własnych potrzeb seksualnych. W literaturze przedmiotu podkreśla się, że osoby niepełnosprawne mają prawo spełniać się seksualnie dla cielesnej rozkoszy i satysfakcji, jaką mogą czerpać z seksu (Ostrowska 2007: 14). Choć potrzeby i preferencje seksualne oraz znaczenia przypisywane aktywności seksualnej mogą być w grupie osób niepełnosprawnych (tak jak i wśród ogółu ludności) zróżnicowane, każdy powinien mieć możliwość decydowania o kształcie własnego życia intymnego.

Z drugiej strony, mimo powyższych postulatów i obecnej w dyskursie naukowym perspektywy dowartościowującej potrzeby seksualne osób niepełnosprawnych, w powszechnych, stereotypowych ujęciach osoby te są niezmiennie przedstawiane jako aseksualne. Co bardziej niepokojące, także popularne modele adaptacji, rehabilitacji czy integracji nie zawierają (lub zawierają zbyt mało) propozycji działań, które mogłyby pomóc osobom niepełnosprawnym w realizacji tych najbardziej osobistych i intymnych potrzeb (Ostrowska 2007: 14). Kulturowo usankcjonowane zepchnięcie na margines potrzeb seksualnych osób niepełnosprawnych powoduje, że proces rehabilitacji w niewielkim stopniu dotyczy sfery seksualnej. Osoby te, ze swoimi fantazjami i potrzebami, ale i frustracjami i trudnościami, zbyt często pozostają same, nierozumiane przez partnerów czy członków rodzin oraz pozbawione wsparcia profesjonalistów, którzy mogliby ułatwić odnalezienie indywidualnego sposobu radzenia sobie $w$ tej trudnej sytuacji.

Zarysowany powyżej problem jest niezwykle złożony. Ze względu na wielość możliwych tropów interpretacyjnych, warto precyzyjnie zaznaczyć, jakie kwestie zostaną poruszone w niniejszym artykule, a jakie wykraczają poza jego ramy. Przede wszystkim, w artykule koncentruję się na sytuacji mężczyzn, którzy zdecydowali się zaspokoić swoje potrzeby seksualne poprzez komercyjne usługi realizowane w agencjach towarzyskich. Jest to jedna z dróg, która w powszechnym postrzeganiu przeznaczona jest dla osób niepotrafiących w inny sposób znaleźć partnera seksualnego, a więc także dla osób niepełnosprawnych ${ }^{1}$. Rzecz jasna, niepełnosprawni mężczyźni nie są skazani na

1 Sposób rozumienia tego, czym jest prostytucja i jakie prawa przysługują osobom, które są w nią zaangażowane jest bardzo zróżnicowany i historycznie zmienny. w starożytności prostytucję postrzegano jako dostępną dla wszystkich mężczyzn drogę realizacji potrzeb seksualnych. Służył temu sposób organizacji i niskie ceny w „publicznych” przybytkach, a także zróżnicowanie oferty, dostosowanej do oczekiwań mężczyzn pochodzących z różnych klas społecznych, od miejskiej biedoty po mieszkańców dworów królewskich i cesarskich (Roberts 1997). z kolei w pismach myślicieli katolickich wczesnego średniowiecza można odnaleźć pogląd, że skoro nie udało się całkowicie wyeliminować prostytucji z życia społecznego, powinna być ona traktowana jako „wentyl bezpieczeństwa”, niezbędne (choć nie chwalebne) wyjście dla mężczyzn, którzy nie są w stanie realizować ideału monogamicznego związku małżeńskiego lub też z różnych względów nie potrafią zdobyć partnerki seksualnej (Karpiński 1997: 31, Roberts 1997, rozdz. IV, Rossiaud 1997: 131). w definicjach prostytucji jeszcze w wieku XX podkreślano, że jedną z jej cech konstytutywnych jest świadczenie usług wszystkim bez wyboru i bez możliwości odmowy (Antoniszyn, Marek 1985: 8). Współczesne ujęcia problemu, na które duży wpływ mają koncepcje feministyczne, można podzielić na kilka nurtów. Na jednym krańcu kontinuum znajdują się podejścia, zgodnie z którymi prostytucja to współczesna forma niewolnictwa (często jest ona utożsamiana z handlem ludźmi), opłacony gwałt, nierozerwalnie związany z przemocą mężczyzn wobec kobiet oraz patriarchalną wizją seksualności (Dworkin 1992, 
korzystanie z prostytucji i nie jest to jedyny dostępny dla nich sposób zaspokajania potrzeb seksualnych. Wielu z nich z powodzeniem poszukuje spełnienia $w$ tej sferze poprzez niekomercyjne relacje, tworząc udane związki, w których seks zajmuje ważne miejsce. Dla wielu osób relacje intymne z obcym, obojętnym emocjonalne człowiekiem, który za wspólnie spędzony czas pobiera opłatę, nie są akceptowalną czy pożądaną drogą zaspokajania własnych potrzeb seksualnych. W artykule przedstawiam więc tylko jeden z możliwych wzorców zachowań niepełnosprawnych mężczyzn, nie przesądzając czy wizyta wagencji towarzyskiej jest jedynym realizowanym przez nich sposobem zaspokajania potrzeb seksualnych.

Warto także zaznaczyć, że podstawą empiryczną niniejszego tekstu są wywiady z pracownicami seksualnymi i ich opowieści o klientach, nie zaś relacje niepełnosprawnych mężczyzn z ich wizyt w agencjach. Celem tekstu jest więc rekonstrukcja obrazu niepełnosprawnego klienta budowanego przez kobiety świadczące usługi seksualne oraz szerzej, sposobu rozumienia przez nie seksualności niepełnosprawnych mężczyzn (sfery postrzeganej powszechnie jako tabu). Jest to o tyle ciekawe, że badane kobiety na co dzień same doświadczają stygmatyzacji społecznej, ściśle związanej ze sposobem rozumienia w naszej kulturze tego, jak powinny być zaspokajane potrzeby seksualne osób dorosłych. W planowanych dalszych badaniach obraz ten zostanie zestawiony z wypowiedziami niepełnosprawnych mężczyzn, którzy udają się do agencji w roli klienta.

Przedmiotem analizy w niniejszym tekście nie jest sytuacja niepełnosprawnych kobiet, choć ich seksualność, wykraczając poza społeczne wyobrażenia i kulturowe skrypty, jest unieważniana i tabuizowana (por. Długołęcka 2012) być może silniej, niż dzieje się to w przypadku niepełnosprawnych mężczyzn. Jednakże punktem wyjścia moich badań są doświadczenia kobiet świadczących usługi seksualne w agencjach towarzyskich. Moje rozmówczynie nie spotkały na terenie agencji niepełnosprawnych (ani pełnosprawnych) kobiet w roli klientek. Z tego względu, choć sfera potrzeb seksualnych kobiet niepełnosprawnych, a także sfera przemocy wobec nich jest niezwykle ważnym obszarem badawczym, wykracza on jednak poza ramy niniejszego tekstu.

Artykuł przedstawia więc tylko wycinek rzeczywistości, nie roszcząc sobie pretensji do opisu złożoności i wielowymiarowości życia seksualnego osób niepełnosprawnych ani też pełnej analizy zjawiska prostytucji. Koncentrując się na sposobach postrzegania osób niepełnosprawnych oraz ich potrzeb przez pracownice agencji, a także na strategiach stosowanych przez nie wobec tej kategorii klientów, przyjmuję jednak, że agencje towarzyskie i komercyjne relacje seksualne są jedną z możliwych dróg realizacji potrzeb przez osoby niepełnosprawne (ze względu na specyfikę polskiego seks biznesu - głównie mężczyzn). Taka droga jest przez niektórych preferowana (choć odwołując się do zgromadzonych przeze mnie danych można wysnuć wniosek, że nie jest to droga łatwo dostępna). Zjawiska te postrzegam jako element rzeczywistości społecznej, wymagający analizy nie oceny.

Jeffreys 2001). Na drugim krańcu kontinuum znajdują się koncepcje traktujące prostytucję jako pracę seksualną, wybór zawodowy kobiety, która może kształtować swoje warunki pracy (między innymi przez wybór klientów i samodzielne decyzje, jakie usługi im świadczyć) i czerpać z niej satysfakcję (Jennes 1990). Szersze rozważania na ten temat wykraczają poza ramy tego artykułu. 


\section{Krótka charakterystyka projektu badawczego}

Dane empiryczne, które stanowią podstawę artykułu, zebrałam w ramach projektu badawczego, dotyczącego sytuacji pracy kobiet świadczących usługi seksualne w agencjach towarzyskich. Projekt realizowałam w jednym z miast wojewódzkich w latach 2007-2013 (Ślęzak 2016) w związku z przygotwaniem dysertacji doktorskiej². Głównymi technikami gromadzenia danych były obserwacje prowadzone przeze mnie w agencjach towarzyskich oraz wywiady swobodne, które przeprowadzałam na terenie badanych lokali z kobietami świadczącymi w nich usługi seksualne. Takie rozwiązanie pozwoliło mi wykorzystać efekt synergii dwóch technik - obserwacji i wywiadów. Informacje uzyskiwane podczas obserwacji stanowiły inspirację dla kolejnych pytań badawczych, na które odpowiedzi szukałam za pomocą wywiadów i odwrotnie, opowieści kobiet podczas wywiadów uwrażliwiały mnie jako obserwatora kolejnych epizodów interakcyjnych. Ze względu na wynegocjowane zasady dostępu do lokali, obserwacje miały charakter jawny dla pracowników, ale ukryty dla klientów. Prowadziłam je systematycznie, zarówno w dni powszednie, jak i weekendy, tak podczas zmian dziennych, jak i nocnych, co umożliwiło rozpoznanie specyfiki działania badanych agencji w różnych warunkach kontekstowych. Badanie zrealizowałam w czterech lokalach, w których oferowano usługi kobiet i których klientami byli wyłącznie mężczyźni (choć nie było ograniczeń, by korzystały z nich także kobiety, takie sytuacje nie miały miejsca). W trakcie realizacji mojego projektu, każda z agencji zatrudniała jednocześnie od kilku do kilkunastu kobiet świadczących usługi seksualne. Od każdej z kobiet starałam się uzyskać zgodę na przeprowadzenie wywiadu swobodnego. Ostatecznie zrealizowałam 56 wywiadów swobodnych mało ukierunkowanych (średni czas trwania wywiadu wynosił około 90 minut - od 35 do 290 minut), a także liczne wywiady nieformalne i konwersacyjne (Konecki 2000: 150), prowadzone w trakcie obserwacji. Badane kobiety miały od 18 do ponad pięćdziesięciu lat, posiadały zróżnicowany staż pracy w agencjach towarzyskich (od kilku dni do kilkunastu lat) oraz różne doświadczenia w spotkaniach z klientami, w tym niepełnosprawnymi. Dobierając kolejne rozmówczynie, starałam się realizować zalecenia teoretycznego doboru (Glaser, Strauss 2009; Gorzko 2008), prowadząc ciągłą analizę porównawczą (constant comparative method, Konecki 2000; Gorzko 2008; Glaser, Strauss 2009) poszczególnych przypadków oraz wyłaniających się pojęć.

Zgromadzone dane empiryczne analizowałam zgodnie z procedurami metodologii teorii ugruntowanej (Glaser, Strauss 2009; Konecki 2000). Materiały, po dokonaniu transkrypcji ${ }^{3}$, poddałam kodowaniu otwartemu, a następnie selektywnemu, podczas którego generowałam kolejne kategorie i ich własności. Jednocześnie, w kodowaniu teoretycznym, budowałam hipotezy, odzwierciedlające wzajemne relacje poszczególnych kategorii (Konecki 2000). Jedną z kluczowych okazała się kategoria interakcji z klientami ${ }^{4}$. Interakcje te, traktowane jako proces, składają się z kilku następujących po sobie faz, których przebieg zależy między innymi od wyniku kategoryzacji klientów odwiedzających agencje. Podczas obserwacji prowadzonych w lokalach oraz w trakcie wywiadów z kobietami świadczącymi usługi seksualne zauważyłam, że nie tylko klienci oceniają pracownice seksualne,

2 Niniejszy artykuł stanowi rozwiniecie wątku jedynie wzmiankowanego w pracy doktorskiej autorki.

${ }^{3}$ Ze względu na wynegocjowane zasady dostępu do badanych lokali oraz warunki uzyskania zgody na wywiady, wszystkie wywiady i obserwacje przeprowadzałam osobiście. Jedynie ja miałam dostęp do plików audio z nagranymi wywiadami, samodzielnie dokonałam także ich transkrypcji.

${ }^{4}$ Przywoływane w artykule kategorie i pojęcia wygenerowane w trakcie analizy oznaczone są kursywą. 
wybierając spośród nich tę, z którą chcą spotkać się na pokoju. Analogicznych oszacowań dokonują także pracownice, próbując przewidzieć, czy spotkanie z danym mężczyzną będzie korzystne (potencjalnie bezpieczne, zyskowne, niezbyt męczące) i podejmując na tej podstawie decyzję czy warto zabiegać o danego klienta. Tym samym, nie są one jedynie bierną stroną interakcji, a ich działania wobec mężczyzn odwiedzających agencję różnią się, w zależności od rezultatu kategoryzacji. Porównując dane dotyczące poszczególnych kategorii klientów zauważyłam, że szczególne reakcje pracownic wzbudzali mężczyźni z niepełnosprawnością. Podstawą empiryczną artykułu są zaobserwowane epizody interakcyjne oraz wypowiedzi kobiet świadczących usługi seksualne odnoszące się do tej kategorii klientów, zaś materiał dla procedury ciągłego porównywania stanowiły dane dotyczące interakcji z pozostałymi kategoriami klientów.

Przy interpretacji danych, wykorzystałam teorie wywodzące się z paradygmatu interpretatywnego, przede wszystkim z symbolicznego interakcjonizmu (Blumer 2007).

\section{Niepełnosprawny mężczyzna w agencji towarzyskiej}

Według badań Zbigniewa Izdebskiego z 2011 na próbie 3200 mieszkańców Polski, 15\% mężczyzn w wieku 15-49 lat ma doświadczenia korzystania z płatnych usług seksualnych ${ }^{5}$ (Izdebski 2012: 769). Trudno jednak określić, jaką część klientów stanowią osoby niepełnosprawne, ponieważ w zasadzie nie ma badań, które dotyczyłyby wyłącznie tej kwestii. Zwykle w literaturze pojawia się jedynie wzmianka o tym, że mężczyźni z dysfunkcjami korzystają z komercyjnych usług seksualnych. Potwierdzają to także wyniki badań empirycznych dotyczących prostytucji, które wskazują, że osoby niepełnosprawne występują w roli klientów. Niepełnosprawny klient agencji jest jednak postacią dość mgliście zarysowaną. Trudno jest określić, kim w ogóle są klienci agencji towarzyskich, co pokazują np. badania przeprowadzone przez zespół Z. Izdebskiego w 2002 roku, na próbie 400 kobiet świadczących usługi seksualne na ulicy i w agencjach w wybranych miastach Polski (lzdebski i in. 2002). Prawie 2/3 respondentek zapytanych o to, kim są ich klienci odpowiedziało, że to „zwykli ludzie". Z perspektywy badanych kobiet, mężczyźni korzystający z usług seksualnych nie wyróżniali się więc w żaden znaczący sposób z ogółu społeczeństwa (Izdebski i in. 2002: 60). Próbując określić środowiska, z jakich pochodzili klienci, respondentki wskazywały kategorie drobnych przedsiębiorców (59\% badanych miała takich klientów), robotników (57\%), turystów z kraju i zagranicy (odpowiednio 51\% i 49\%), studentów (50\%), zawodowych kierowców (44\%), policjantów i woj.skowych (39\%), emerytów (39\%), bogatych biznesmenów (37\%) oraz osoby ze środowisk przestępczych (wskazało ich 35\% respondentek) (Izdebski i in. 2002: 61). Z komercyjnych usług seksualnych korzystają więc mężczyźni z różnych grup i kategorii społecznych, zawodów, grup wiekowych, itd. Według deklaracji badanych kobiet, 20\% z nich świadczyła usługi "osobom niepełnosprawnym, inwalidom" (Izdebski i in. 2002: 61). Ze względu na narzędzie badawcze (kwestionariusz wywiadu) oraz ilościowy charakter badań nie sposób jednak określić, jakie znaczenia respondentki przypisywały określeniom zawartym w kafeterii, a tym samym jak rozumiały "niepełnosprawność" czy "inwalidztwo". Trudno więc stwierdzić, jakiego rodzaju dysfunkcje charakteryzowały klientów, którzy korzystali z ich usług oraz określić czy dominowały wśród nich osoby z pewnymi rodzajami niepełnosprawności. Miejscem świadczenia usług seksualnych niepełnosprawnym klientom były

${ }^{5}$ Jest to nieco wyższy odsetek niż w poprzednich badaniach zespołu Z. Izdebskiego z 2001 i 2005 roku, gdzie oscylował on wokół 12\% (Izdebski 2006: 70). 
zwykle ich domy czy mieszkania, zaś w organizację takich spotkań angażowali się także ojcowie dorosłych mężczyzn, niektórzy systematycznie. Z. Izdebski wspomina, że dla części z nich wiązało się to $z$ dylematami, czy pozwolić i ułatwić synom takie spotkania. Kluczowe w tym przypadku było akceptowanie takiego sposobu zaspokajania potrzeb seksualnych synów (Izdebski 2006: 29-30).

Wiedzę na temat niepełnosprawnych mężczyzn korzystających z komercyjnych usług seksualnych uzupełnia także przeprowadzone przeze mnie badanie dotyczące sytuacji pracy kobiet w agencjach towarzyskich. Ze względu na jakościowy charakter badań i wykorzystane techniki gromadzenia danych, możliwe było zrekonstruowanie tego, jak pracownice seksualne, deklarujące odbywanie interakcji z niepełnosprawnymi klientami, definiowały niepełnosprawność i na jakiej podstawie klasyfikowały konkretnych mężczyzn jako niepełnosprawnych.

Przede wszystkim należy zauważyć, że kategoria „klientów niepełnosprawnych” stanowiła dla badanych kobiet jeden z typów tzw. kłopotliwych czy trudnych klientów, czyli takich, z którymi spotkanie na pokoju odbiegało od typowych, standardowych zdarzeń i wymagało wzmożonego wysiłku interpretacyjnego i interakcyjnego. Definiowanie danego mężczyzny jako osoby niepełnosprawnej odbywało się poprzez postrzeganie widocznych (łatwych do zaobserwowania przez pracownice) dysproporcji i dysfunkcji ciała. Do tego grona zaliczano więc przede wszystkim osoby niepełnosprawne fizycznie ${ }^{6}$, ale także takie, których ciało odbiegało od kulturowo akceptowanego wzorca, choć niekoniecznie było niepełnosprawne. Co znamienne, wśród klientów, z którymi rozmówczynie miały kontakt podczas pracy w agencji, nie było osób głuchoniemych czy ociemniałych, a także niepełnosprawnych intelektualnie. Z agencji towarzyskiej, jako sposobu realizacji potrzeb seksualnych, korzystały więc osoby niepełnosprawne fizycznie, których dysfunkcja umożliwiała im samodzielne poruszanie się i nie zakłócała znacząco procesu komunikacji. W przeciwieństwie do respondentek z badania Z. Izdebskiego, moje rozmówczynie nie wspominały o wizytach wyjazdowych do domów klientów ${ }^{7}$. Choć bazuję jedynie na deklaracjach badanych pracownic (a próba badawcza nie była reprezentatywna) można zauważyć, że do agencji towarzyskich nie trafiają osoby, których niepełnosprawność utrudnia komunikowanie się i poruszanie w sposób znaczny. Biorąc pod uwagę konieczność przyjazdu do lokalu, uiszczenia opłat i realizowania wzoru interakcji, który obowiązuje podczas spotkania z pracownicą, nie jest to więc droga dostępna dla wszystkich.

\section{Przebieg spotkania w agencji towarzyskiej}

Agencja towarzyska jest miejscem, w którym klientom (przede wszystkim mężczyznom) oferuje się towarzystwo (nieoficjalnie także usługi seksualne) pracujących w niej kobiet. Przebieg takiej interakcji w swej ogólnej formie jest dość ściśle ustalony i w bardzo zbliżonym kształcie przetrwał od czasów starożytnych lupanarów (por. Roberts 1997). Obie strony interakcji działają w ramach jasno określonych (choć niepisanych) zasad przebywania w lokalu, co powoduje, że przebieg spotkania

${ }^{6}$ Obserwacja ta jest zbieżna z wynikami badań A. Ostrowskiej (1997). Zgodnie z jej ustaleniami, w potocznym wyobrażeniu pod pojęciem "niepełnosprawny” kryje się osoba z uszkodzonym narządem ruchu, widocznym w interakcji (niepełnosprawności sensoryczne). Popularne rozumienie jest więc węższe od oficjalnych, np. medycznych kryteriów orzeczniczych. Obraz ten utrwalają media, rzadko pokazując wizerunki innych niż fizyczne niepełnosprawności (Ostrowska 1997: 82).

7 Może być to związane z przemianami rynku usług seksualnych w ciągu ostatnich lat oraz jego lokalną specyfiką. w badanych przeze mnie w latach 2007-2013 lokalach, systematycznie spadała liczba spotkań aranżowanych w domach klientów. Tzw. wyjazdy realizowano jedynie do hoteli. 
jest w dużej mierze przewidywalny. Pozwala to pracownicom, w miarę zdobywanego doświadczenia, wypracować sposoby radzenia sobie z klientami (w tym rozpoczynania, prowadzenia i kończenia interakcji), a także takiego doboru klientów, by maksymalizować swoje korzyści i minimalizować ryzyko.

Choć w potocznym ujęciu wydaje się, że jedynie klienci oceniają i wybierają spośród kobiet obecnych w agencji towarzyskiej tę, z którą chcą spędzić czas, wyniki przeprowadzonych przez mnie badań pokazują, że zwykle sytuacja ta jest bardziej symetryczna ${ }^{8}$. Już od pierwszych minut obecności klientów w lokalu, są oni dokładnie obserwowani i kategoryzowani przez pracownice. W odniesieniu do mężczyzn, którzy są bywalcami danego lokalu mogą one odwoływać się do doświadczeń własnych lub współpracownic. Jednakże w przypadku nowego klienta kategoryzacja bazuje jedynie na postrzeganych atrybutach zewnętrznych, a więc na pierwszym wrażeniu wywoływanym przez mężczyznę podczas interakcji na salonie. Podstawowymi kryteriami kategoryzacji są: ocena wieku, wyglądu fizycznego, stroju, zapachu klienta, jego zachowania wobec kobiet i innych gości oraz oczekiwań, co do przebiegu spotkania seksualnego (Ślęzak 2016, w zależności od oszacowanej „wartości" klienta w tych „wymiarach”, pracownice agencji podejmują mniej lub bardziej intensywne starania o to, by spędzić z danym mężczyzną czas na pokoju. Działania te są tym bardziej intensywne, im korzystniejsze wydaje się pracownicy potencjalne spotkanie z klientem, tzn. mężczyzna wygląda na zamożnego i hojnego, względnie spokojnego (nie wykazującego oznak agresji), podatnego na perswazje, niezbyt wymagającego w kwestii przebiegu interakcji seksualnej. Jeśli natomiast w wyniku kategoryzacji klient oceniany jest jako mało atrakcyjny, pracownice niezbyt chętnie podejmują z nim interakcję, koncentrując się na tych klientach, którzy wypadają w klasyfikacji lepiej. W skrajnych przypadkach mogą nawet odmówić kontaktu z klientem, który, jeśli nie znajdzie w danej agencji pracownicy chętnej do spotkania z nim, musi opuścić lokal. Rzecz jasna, biorąc pod uwagę zyski finansowe tak pracownic jak i agencji, tego typu reakcje odmowne stanowić muszą zdecydowaną mniejszość i powinny być stosowane w uzasadnionych przypadkach. W badanych agencjach takie sytuacje zdarzały się wobec agresywnych, niewypłacalnych oraz niepełnosprawnych klientów. Mimo zrozumiałej niewspółmierności tych trzech sytuacji osoby niepełnosprawne były w badanych agencjach zaliczane w poczet mniej pożądanych klientów. Świadczy o tym także fakt, że $w$ trakcie siedmiu lat realizowania projektu nie poznałam pracownicy, która wyspecjalizowałaby się w spotkaniach z osobami niepełnosprawnymi, choć poznałam wiele kobiet specjalizujących się w kontaktach z klientami o specyficznych fantazjach czy potrzebach seksualnych (np. BDSM, różnego rodzaju fetysze). Może to świadczyć o „płytkim” rynku na tego rodzaju usługi (przynajmniej w badanym mieście), ale i o tym, że pracownice nie postrzegają osób niepełnosprawnych jako „dobrych” klientów. Niepełnosprawni mężczyźni, którzy odwiedzali badane agencje byli więc narażeni na odmowę realizacji spotkania seksualnego lub też niechętne jego przeprowadzanie, co wiązało się z nikłym zaangażowaniem pracownicy w interakcję seksualną czy nieprzyjemnym komentowaniem jej przebiegu. Wpływ na to miał niewątpliwie rezultat przeprowadzanej przez pracownice kategoryzacji. Szczególne znaczenie miały w niej kryteria związane z estetyką klientów nie-

${ }^{8}$ Rzecz jasna dotyczy to tych agencji, w których nie dochodzi do przetrzymywania kobiet, zmuszania ich do świadczenia usług seksualnych, przemocy wobec nich. Jeśli nie są spełnione wyżej wymienione warunki, trudno mówić o symetryczności relacji. 
pełnosprawnych oraz przewidywaną problematycznością interakcji, wynikającą z kłopotów technicznych i organizacyjnych podczas spotkania na pokoju.

\section{Estetyczny wymiar interakcji}

Jak już wspomniałam, poprzez proces kategoryzacji klientów pracownice agencji towarzyskich próbują przewidzieć i zaprojektować przebieg potencjalnego spotkania, by na tej podstawie ocenić jego trudność, ale także możliwe korzyści. O ile szereg niepożądanych z ich perspektywy cech klienci mogą starać się ukryć czy pokazać w innym świetle (np. udając, że dysponują większą sumą pieniędzy niż faktycznie mają), niepełnosprawność w wielu jej aspektach jest tym atrybutem, który czyni z danego mężczyzny osobę, używając terminologii E. Goffmana, zdyskredytowaną (Goffman 2005: 34). Ukrycie czy zamaskowanie dyskredytujących atrybutów jest często niemożliwe, gdyż są one ewidentne, widoczne na pierwszy rzut oka lub najpóźniej w momencie rozpoczęcia interakcji seksualnej. Ten rodzaj piętna jest więc nie tylko widoczny, ale charakteryzuje się także potencjalnie dużą natarczywością (Goffman 2005: 85) i percepcyjnym „zagęszczeniem” (Goffman 2005: 86) podczas interakcji.

Jedną z płaszczyzn, na których zachodzi odrzucenie klientów niepełnosprawnych jest niski poziom estetyki ciała, wokół którego rozgrywa się spotkanie na pokoju. Wszelkie deformacje, które oddalają ciało od "typowego", przyjętego w naszej kulturze wzorca mogą być powodem odczuwanego obrzydzenia, a w rezultacie odrzucenia klienta:

Niepełnosprawni przychodzą, ale nie obsługujemy. Mieliśmy pana kiedyś bez nogi, przyszedł i poszedł, mieliśmy kiedyś pana z takim jajkiem do kolan. Ja nie obsługuję takich klientów, ja musiałabym mieć jakąś torebkę, która by leżała obok łóżka. [22-letnia pracownica agencji z kilkumiesięcznym stażem]

Wstręt odczuwany przez pracownice podczas (nawet antycypowanego) kontaktu ze zmienionym ciałem, może dotyczyć zarówno jego wyglądu jak i higieny osobistej. Badane kobiety często utożsamiały ciało ułomne z ciałem brudnym, co jest o tyle zrozumiałe, że osoby niepełnosprawne fizycznie faktycznie miały duże trudności ze skorzystaniem z obowiązkowego przed spotkaniem seksualnym prysznica. W badanych agencjach łazienki nie były przystosowane do tego rodzaju klientów ${ }^{9}$, nie mogli oni także liczyć na niczyją pomoc:

Ja miałam tutaj taki przypadek, że przyszedł pan, który był bez nogi, miał protezę, nie chciał się iść umyć, ponieważ było to dla niego ciężkie i wtedy mu odmówiłam. Szef się zgodził. Była taka sytuacja, że przyszedł pan, mimo iż ta choroba nie jest zaraźliwa, ale skórna, taka choroba, która jest genetyczna, którą się nie zarażasz, z łuszczycą. Też mu odmówiłam. Przyszedł pan, który yyy jądra miał wielkości twojej głowy to też mu odmówiłam. Aha i kiedyś przyszedł tutaj bardzo mały karzeł i któraś z dziewczyn też mu odmówiła, a to dlatego, że powiedziała,

9 Żaden z badanych lokali nie był architektonicznie przystosowany do potrzeb niepełnosprawnych klientów. Wysokie, strome schody, brak wind i podjazdów, wąskie drzwi, ciasne i/lub niedostosowane łazienki, pokoje (brak drążków, poręczy, itd.) faktycznie czyniły przestrzeń agencji niedostępną dla klientów, którzy mają problemy z poruszaniem się. 
że jak on się rozbierze, to ona będzie się cały czas śmiała. [28-letnia pracownica agencji z 8-letnim stażem]

Reakcje na cielesność odbiegającą od obowiązujących kanonów urody były więc nie tylko negatywne, ale i upokarzające dla klientów - nie mogli oni liczyć na zaspokojenie potrzeb seksualnych przez kobiety, które ze względu na sposób zarobkowania same nierzadko odczuwały społeczne napiętnowanie i wykluczenie. Co warto zauważyć, relacjonując swoje (zwykle niedoszłe) interakcje z niepełnosprawnymi klientami, pracownice traktowały je w analogiczny sposób jak wizyty mężczyzn w podeszłym wieku, z patofizjologicznymi zmianami członka czy jąder, ale także z niektórymi chorobami (np. skóry). Z ich perspektywy należeli oni do tej samej kategorii klientów, których ciało różniło się wyglądem od "typowego" na tyle, by dyskwalifikowało ich to jako pożądanych partnerów w świecie komercyjnych usług seksualnych. Tym samym, pracownice minimalizowały niewątpliwe różnice w sytuacji zdrowotnej i życiowej mężczyzn odwiedzających agencje, uwypuklając podobieństwa wynikające z przebiegu interakcji z klientami określanymi przez nie jako kłopotliwi czy trudni. Jednocześnie do tej kategorii zazwyczaj nie zaliczały one np. mężczyzn z zaburzeniami wzwodu (poza przypadkami, gdy zachowywali się oni agresywnie), co może oznaczać, że to wygląd ciała, a nie jego sprawność seksualna, miał kluczowe znaczenie dla postrzegania klientów. Klient z zaburzeniami erekcji często był określany jako łatwy, gdyż szybko można było przekonać go do zmiany scenariusza spotkania i skoncentrować się na rozmowie lub delikatnych pieszczotach ${ }^{10}$. W przypadku klientów z niepełnosprawnościami czy deformacjami ciała również można było (a zapewne w wielu przypadkach było to konieczne) zastosować inne niż "typowe" pozycje i działania seksualne, które przez obie strony byłyby akceptowalne i prowadziły do zaspokojenia potrzeb klienta. Badane pracownice seksualne nie decydowały się jednak na podejmowanie takich działań.

\section{Kłopoty „techniczne”}

Niepodejmowanie interakcji seksualnych z niepełnosprawnymi mężczyznami miało także swe przyczyny w lęku związanym z brakiem wiedzy rozmówczyń na temat istoty dysfunkcji, jej wpływu na możliwość zrealizowania stosunku seksualnego, a co za tym idzie, trudności z wyobrażeniem sobie jak takie spotkanie mogłoby przebiegać. Pracownice często nie potrafiły nazwać rodzaju dysfunkcji danego klienta (podczas wywiadów opisywały jedynie jej zewnętrzne oznaki). Nie były także świadome, na ile ta niepełnosprawność była poważna, w jakim stopniu mogła wpłynąć na przebieg aktu seksualnego i w jaki sposób „technicznie” go przeprowadzić. Pracownice, które decydowały się na podjęcie takiej próby, szybko się zniechęcały i nierzadko wprost komunikowały klientowi swoje niezadowolenie, jednocześnie całkowicie obwiniając go za niepowodzenie spotkania. Takie działanie można interpretować jako próbę obrony swojej profesjonalnej tożsamości (jako sprawnej pracownicy seksualnej, potrafiącej poradzić sobie z różnymi klientami) oraz/lub dążenie, by odwieść niezadowolonego klienta od zgłoszenia osobie zarządzającej lokalem ewentualnej skargi ${ }^{11}$. Zawstydzenie czy upokorzenie klienta jest także sposobem na to, by skutecznie zniechęcić go do ponownego przyjścia do agencji i danej pracownicy, co uwalnia ją tym samym od konieczności interakcji

10 Wyjątek stanowili klienci, których trudności były efektem zażytych środków psychoaktywnych i/lub obwiniający pracownice za swoje niepowodzenia seksualne i zachowujący się w stosunku do nich agresywnie.

${ }^{11}$ Niektórzy klienci, niezadowoleni z usługi seksualnej, zgłaszali reklamację, domagając się od osoby zarządzającej lokalem zwrotu uiszczonej opłaty. 
w przyszłości. Z perspektywy badanych kobiet, wizyta klienta z różnego rodzaju dysfunkcjami była niechciana również dlatego, iż wymagała z ich strony niestandardowych, nietypowych działań, wykraczających poza pewien dobrze opanowany przez nie scenariusz spotkania z klientem. Niepełnosprawni mężczyźni siłą rzeczy oczekiwali bardziej indywidualnego podejścia ${ }^{12}$, wyczulenia na ich potrzeby czy gotowości na eksperymenty (np. odkrywania nowych stref erogennych, por. Cencora, Pasiut 2012), zaś pracownice w badanych agencjach nie były gotowe (ani w sensie przygotowania merytorycznego, ani emocjonalnego czy motywacyjnego), by tym oczekiwaniom sprostać i tworzyć nowe scenariusze przebiegu spotykania na pokoju. Obawiając się reakcji zmienionego ciała, nie widziały siebie w roli osób, które pomagają klientom niepełnosprawnym odkrywać i realizować ich seksualność. Co ciekawe, relacjonując swoje spotkania z "typowymi” klientami, badane często porównywały swą rolę do psychologa, który wysłuchuje i wspiera (Ślęzak 2016). Jednak zakres ich pomocy obejmował podnoszenie na duchu jedynie w typowych, codziennych problemach (np. „żona mnie nie rozumie”). Z tej perspektywy klient niepełnosprawny stanowił zwykle zbyt duże wyzwanie interakcyjne.

Nie powinno więc dziwić, że mężczyźni niepełnosprawni nie byli częstymi gośćmi w badanych agencjach, nie byli w nich także oczekiwani. Każdorazowe przyjście takiego klienta było żywo i długo komentowane w gronie pracownic, stanowiąc swego rodzaju sensację bądź ciekawostkę. Pracownice omawiały zarówno domniemane przyczyny wizyty, jak i swoją reakcję na obecność i oczekiwania klienta, a wreszcie potencjalne sposoby zachowania się w analogicznych sytuacjach w przyszłości. W tych spontanicznie toczących się rozmowach zazwyczaj wyrażano niezrozumienie, po co klienci z dysfunkcjami ciała przyszli do agencji i jak wyobrażali sobie przebieg spotkania. Dla części badanych kobiet, stosunek seksualny czy nawet inna forma pobudzania sfer erogennych mężczyzn niepełnosprawnych była bowiem nie do pomyślenia. Jak już wcześniej wspomniałam, podobne reakcje wywoływały także wizyty najstarszych klientów, czyli tych, którzy według wypowiedzi badanych pracownic mieli powyżej 70 lat (choć trzeba zaznaczyć, że do tej grupy nierzadko byli zaliczani i młodsi mężczyźni, jeśli ich ciało "nie było zadbane”). „Tradycyjny" (a zarazem najprostszy) sposób zaspokajania ich potrzeb (klasyczny stosunek seksualny) wydawał się pracownicom nie do zrealizowania. Widoczny był także z ich strony brak wystarczającego zaangażowania, by wspólnie z klientem poszukać alternatywnych dróg przebiegu spotkania. Choć opowieści pracownic o innych, bardziej „typowych" klientach świadczą o tym, że niestandardowe czynności seksualne są w agencjach raczej codziennością niż wyjątkiem, nie są one realizowane z klientami „odbiegającymi cieleśnie od normy". Według moich rozmówczyń, stare lub niesprawne ciało nie powinno więc mieć potrzeb seksualnych ${ }^{13}$.

\footnotetext{
${ }^{12}$ W zasadzie wielu klientów, nie tylko niepełnosprawnych, liczy na zdindywidualizowane podejście, nierzadko oczekując od pracownicy, by weszła w rolę zauroczonej dziewczyny czy kochanki (tzw. "The Girlfriend Experience”, Sanders 2008). W przypadku "typowych" spotkań wiele pracownic stosowało wypracowane sposoby (o różnej skuteczności i stopniu wyrafinowania) odgrywania takiego zainteresowania. Porządek występu był jednak nie tylko zaburzany, ale wręcz niszczony, gdy jednym z partnerów interakcji był mężczyzna niepełnosprawny, dla którego pracownica nie miała wypracowanych skryptów postępowania.

13 W badaniu prowadzonym przez Z. Izdebskiego wśród kobiet świadczących usługi seksualne, najliczniejsza grupa badanych (31\%) twierdziła, iż zainteresowanie mężczyzn seksem spada po osiągnięciu przez nich 70 roku życia. $27 \%$ badanych określiło tę granicę na 60-69 lat, 23\% na 50-59 lat, zaś 15\% na 40-49 lat (Izdebski 2002: 64).
} 


\section{Dyskusja}

Na podstawie wyników przeprowadzonych przeze mnie badań można stwierdzić, że uczestniczące w nich pracownice agencji towarzyskich podzielają powszechne w społeczeństwie przekonania dotyczące potrzeb seksualnych osób z dysfunkcjami ciała. W pewnym sensie jest to konstatacja oczywista, ponieważ w trakcie procesu socjalizacji przyswoiły one sobie, podobnie jak ogół społeczeństwa, zestaw wyobrażeń na temat tego, czego osoba niepełnosprawna powinna oczekiwać od życia w zakresie swoich potrzeb intymnych. Z drugiej jednak strony, dystans i niezrozumienie dla obecności osób niepełnosprawnych w agencjach towarzyskich może jednak dziwić, gdyż, jak pokazują te same badania (Ślęzak 2016), pracujące w agencjach kobiety wykazywały dalece większe zrozumienie dla niestandardowych czy nawet powszechnie nieakceptowanych praktyk seksualnych oczekiwanych przez "typowych” klientów. Choć nie wszystkie rozmówczynie godziły się na ich realizację i niejednokrotnie budziły w nich one odrazę czy nawet wstręt, jednak w takich sytuacjach raczej starały się nakłonić klienta do wyboru innej usługi, nie rezygnując ze spotkania. W przypadku osób, których ciało nie spełniało powszechnych norm estetycznych często do spotkania z osobą niepełnosprawną wogóle nie dochodziło. Badane kobiety (świadomie lub nie) podzielały więc patriarchalną wizję seksualności uważając, że mężczyzna może poszukiwać w agencji towarzyskiej realizacji tych fantazji, o których wstydzi się powiedzieć żonie/partnerce lub których ona kategorycznie odmawia. Jednakże "prawo" to nie obejmowało mężczyzn niepełnosprawnych i starych.

Prowadząc badania w agencjach towarzyskich obserwowałam spotkania oraz słuchałam relacji o całym spektrum klientów odwiedzających takie miejsca. Nie każdy z gości agencji był zamożny, atletycznie zbudowany i zadbany (także pod względem higieny osobistej). Bywali klienci nieuprzejmi, agresywni czy pod wpływem środków psychoaktywnych. Także oczekiwania seksualne niektórych z nich daleko wykraczały poza te akceptowane przez pracownice i wiązały się z czynnościami, których kobiety nie lubiły wykonywać i unikały w swoim pozaagencyjnym życiu seksualnym. Innymi słowy, kontakty z pewnymi kategoriami klientów mogły być dla pracownic trudne lub nieprzyjemne, a nawet niebezpieczne. Jednakże wizyty tego typu klientów nie wywoływały takiego zdziwienia i poruszenia, jak to działo się w przypadku klientów niepełnosprawnych. Kluczowym elementem, który różnicuje te kategorie klientów jest fakt, że "typowi” (nawet, jeśli to określenie dotyczy mężczyzn pod wpływem alkoholu czy nieuprzejmie odnoszących się do pracownic) są "oswojeni" zarówno poprzez własne doświadczenia, jak i opowieści innych pracownic. Snucie opowieści o klientach ma walor pedagogizujący nowicjuszki - tą drogą przekazywane są im zarówno wskazówki techniczne (jak skutecznie stosować różne pozycje seksualne), jak i wiedza ogólna - czego można spodziewać się i oczekiwać po spotkaniu z klientem, jak ono zwykle przebiega, jaki jest zestaw profesjonalnych "trików”, by klient był zadowolony ze spotkania, a jednocześnie pracownica nie musiała zbytnio się w nie angażować (por. Ślęzak 2014b). Te elementy wiedzy zawodowej ulegają zawieszeniu przy klientach, którzy znacząco odbiegają od „typowego" gościa agencji. Wymagają oni innych sposobów postępowania, często silnie zindywidualizowanych ze względu na posiadane dysfunkcje, a nabyte przez kobiety umiejętności z trudem dają się przenieść na kolejne interakcje z niepełnosprawnymi klientami. Relatywnie mała liczba mężczyzn z niepełnosprawnościami, którzy trafiali do badanych lokali (w przeciwieństwie do dużej liczby klientów z różnymi fantazjami seksualnymi) nie pozwala żadnej ze stron na zdobycie doświadczeń, które ułatwiałyby interakcję i uwalniały obie strony od lęków i obaw. Ponieważ pracownice z większym stażem także zwykle nie 
miały podobnych doświadczeń, jedynym wzorcem, jaki w tej sytuacji przekazywały nowicjuszkom, była rezygnacja ze spotkania i zniechęcenie klienta. Reakcją na nowość poznawczą i interpretacyjną (jak poradzić sobie z klientem, którego cielesność odbiega od typowych doświadczeń z agencji) jest

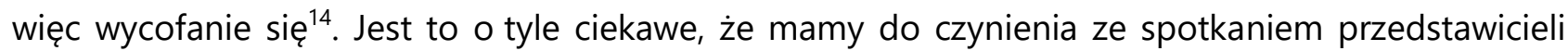
dwóch kategorii społecznych, które naznaczone są stygmatem i w relacjach z normalsami doświadczają wielu problemów interakcyjnych (Goffman 2005). Tymczasem okazuje się, że także do interakcji tych dwóch zdyskredytowanych (Goffman 2005) grup w agencjach towarzyskich pracownice stereotypy i uprzedzenia, które utrudniają czy wręcz uniemożliwiają porozumienie i realizację spotkania.

W przypadku niepełnosprawnych mężczyzn, którzy chcieliby skorzystać z usług seksualnych, kluczową kwestią wydaje się więc właściwy dobór partnera/ki i miejsca takiego spotkania. W książce Pełnosprawni! Uniwersalny przewodnik po seksie dla tych, którzy żyją z niepełnosprawnością, chronicznym bólem i chorobą (Silverberg, Fran, Kaufman 2013) wśród porad pracownic seksualnych dla osób niepełnosprawnych, które są zainteresowane tego typu usługami, można znaleźć wskazówkę, by nie korzystać z usług agencji i przypadkowych osób. Może się to bowiem wiązać z licznymi niebezpieczeństwami (np. ryzyko zostania okradzionym czy pobitym), ponieważ niepełnosprawny klient bywa postrzegany jako łatwa ofiara nadużyć. Aby spotkanie było satysfakcjonujące, warto udać się do osoby poleconej przez innego klienta oraz sprawdzić czy jest ona gotowa na spotkanie, czyli np. jest przygotowana do ewentualnego udzielenia pomocy w samoobsłudze czy przyjęciu odpowiedniej pozycji, by poradzić sobie z problemami seksualnymi związanymi z różnymi rodzajami niepełnosprawności.

Jedną z propozycji dla osób niepełnosprawnych (tak mężczyzn jak i kobiet), które nie mogą realizować swoich potrzeb seksualnych z własnymi partnerami i nie chcą korzystać z prostytucji, a także tych, które (analogicznie jak osoby pełnosprawne), choć mogłyby znaleźć partnerów, wybierają komercyjne usługi seksualne, jest pomoc asystentów i terapeutów seksualnych (Długołęcka, Fornalik 2013; Ślęzak 2014c). Zwolennicy tych rozwiązań podkreślają profesjonalny charakter oferowanego wsparcia, który przejawia się między innymi tym, że aby zostać zastępczym partnerem-terapeutą zrzeszonym w International Professional Surrogates Association (IPSA), oprócz predyspozycji osobowościowych, konieczne jest ukończenie szeregu kursów, uzyskanie certyfikatu zawodowego i współpraca z zarejestrowanym seksuologiem. Profesjonalny charakter terapii seksualnej ma podkreślać także kodeks etyczny IPSA ${ }^{15}$. który stoi na straży jakości pracy partnerów zastępczych. Analogicznie, asystenci seksualni osób niepełnosprawnych, aby pełnić swoje zadanie profesjonalnie, powinni odbyć kursy teoretyczne i praktyczne, obejmujące elementy psychologii, wiedzy o niepełnosprawności i seksualności niepełnosprawnych, masażu i technik masturbacji. Współpraca z asystentem czy terapeutą seksualnym miałaby być sposobem na to, by późniejsze korzystanie z komercyjnych usług seksualnych stało się bezpieczniejsze i bardziej komfortowe.

14 O braku ukształtowanych wzorców interakcji między osobami niepełnosprawnymi i "sprawnymi” oraz o koncentrowaniu się w potocznych wyobrażeniach o niepełnosprawnych na ich słabościach i ograniczeniach pisała A. Ostrowska (1997). w jej badaniach prawie $60 \%$ badanych deklarowała, że unika kontaktów z niepełnosprawnymi, ponieważ nie wie czy nie jest pewna jak się zachować w ich obecności (Ostrowska 1997: 86).

15 Patrz http://www.surrogatetherapy.org/code-of-ethics. 
Jednak idea asystentury seksualnej budzi liczne kontrowersje (szczególnie w przypadku osób niepełnosprawnych intelektualnie). Pojawiają się głosy, że taki sposób zaspokajania potrzeb może obniżać samoocenę osób niepełnosprawnych i uderzać w ich godność (por. (Tederko 2007; Długołęcka, Fornalik 2013). Terapia bywa także utożsamiana z prostytucją (zob. Fairbairn, Rowley 2005), choć, przynajmniej w założeniu, ma inne, terapeutyczne cele. Także osoby niepełnosprawne, które są propagatorami idei asystentów seksualnych (np. Marcel Nuss, mężczyzna z całkowitym porażeniem czterokończynowym, założyciel organizacji Coordination Handicap et Autonomie czy Aiha Zemp z organizacji Fabs, działającej na rzecz dostępu osób niepełnosprawnych do refundowanej pomocy asystentów seksualnych) są zdania, że do tego rodzaju wsparcia kwalifikują się jedynie te osoby niepełnosprawne, które nie mają innej możliwości realizowania swoich potrzeb seksualnych, nawet na drodze autoerotyki (Długołęcka, Fornalik 2013: 168). W Polsce pytanie o akceptację usług asystenta seksualnego zadano w badaniu realizowanym na próbie osób po urazie rdzenia kręgowego. Większość z 30 badanych była pozytywnie nastawiona do idei wprowadzenia asystenta seksualnego dla osób, które zgłosiłyby taką potrzebę, zaś 1/3 respondentów rozważałaby skorzystanie z takich usług (Długołęcka, Izdebski, Radomski 2010 za Długołęcka, Fornalik 2013: 168). Wydaje się, że w naszych warunkach byłaby to droga właściwa i pod wieloma względami bardziej korzystna, niż interakcje osób nepełnosprawnych z pracownicami agencji towarzyskich, opisane w artykule na podstawie badań własnych. Ewentualne wprowadzenie w naszym kraju takich rozwiązań, oraz związanych z nimi szkoleń, nadzoru, a przede wszystkim szczegółowych zasad korzystania z terapii seksualnej, wymagałoby jednak głębszej dyskusji.

\section{Podsumowanie}

Potrzeby seksualne osób niepełnosprawnych, mimo ich obecności w dyskursie naukowym i terapeutycznym, wciąż pozostają zapoznane dla ogółu naszego społeczeństwa. Także kobiety świadczące usługi seksualne, choć w swojej praktyce spotykają się z różnymi klientami o silnie zróżnicowanych potrzebach i fantazjach, nie mają zbyt wielu doświadczeń z niepełnosprawnymi mężczyznami. Mężczyźni ci są zazwyczaj postrzegani jako pozbawieni potrzeb seksualnych, jeśli zaś przychodzą oni do agencji, uznawani są za kłopotliwych i niechcianych klientów. W rezultacie doświadczają oni odmowy (nie zawsze w delikatny sposób) przed lub już w trakcie spotkania. Jak wskazują wyniki badań Z. Izdebskiego, jednym z podstawowych lęków zarówno mężczyzn jak i kobiet w relacjach intymnych jest obawa, że nie sprawdzą się podczas stosunku seksualnego ${ }^{16}$. Obawy te są przypuszczalnie jeszcze silniejsze wśród osób niepełnosprawnych, ponieważ ich ciała są mniej sprawne i jeszcze bardziej odległe od medialnych kanonów piękna (Ostrowska 2007: 16). Reakcja pracownic agencji na niepełnosprawnych klientów oraz przebieg spotkania może wpłynąć negatywnie na ich ewentualne kolejne próby realizacji swoich potrzeb, nie tylko na gruncie komercyjnych usług seksualnych. Rzecz jasna, agencje towarzyskie nie są instytucjami pomocowymi, skierowanymi do osób niepełnosprawnych, jednakże zaobserwowany sposób prowadzenia interakcji przez pracownice agencji z tego rodzaju klientami (będący pochodną obecnego poziomu edukacji seksualnej i wiedzy potocznej na temat potrzeb i możliwości osób niepełnosprawnych w sferze seksual-

${ }^{16}$ Na pytanie: „czego ludzie boją się przede wszystkim w relacjach seksualnych?” badane kobiety (N=1585) i mężczyźni ( $\mathrm{N}=1615)$ wskazywali odpowiednio, obok głównych obaw (ciąża, HIV), że nie sprawdzą się w seksie (27\% kobiet i 32\% mężczyzn), oceny ich sprawności seksualnej (23\% i 32\%), oceny ich wyglądu (14\% i 10\%), nieprzyjemnych wspomnień (10\% i 6\%), że nastąpią problemy w trakcie współżycia (6\% i 8\%) (Izdebski 2006: 72). 
nej) pozwala poddać w wątpliwość ich rolę w zaspokajaniu potrzeb osób, których cielesność odbiega od przyjętej normy.

\section{Bibliografia}

Antoniszyn, Michał, Marek, Andrzej. 1985. Prostytucja w świetle badań kryminologicznych. Warszawa: Wydawnictwo Prawnicze.

Blumer, Herbert. 2007. Interakcjonizm symboliczny. Tłum. G. Woroniecka. Kraków: Zakład Wydawniczy NOMOS.

Cencora, Monika, Pasiut, Szymon. 2012. Rehabilitacja seksualna po urazie rdzenia kręgowego. W: „Fizjoterapia” 20, s. 12-31.

Długołęcka, Alicja. 2012. Seks kobiet po urazie rdzenia kręgowego. W: (red.) Klukowski, Krzysztof. Medycyna sportowa. Część druga. Warszawa: Medical Tribune Polska, s. 320-324.

- - -, Fornalik, Izabela. 2013. Usługi seksualne w procesie rehabilitacji seksualnej osób z niepetnosprawnoscia ruchowa i intelektualna. W: (red.) Kowalczyk, Robert, Leśniak, Małgorzata. Prostytucja. Studium zjawiska. Kraków: Oficyna Wydawnicza AFM, s. 161-193.

Dworkin, Andrea. 1992. Prostitution and Male Supremacy. http://prostitutionresearch.com/ pub author/andrea-dworkin; dostęp: 05.01.2015.

Fairbairn, Gavin, Rowley, Denis. 2005. Etyczne aspekty seksualności osób z niepetnosprawnościa intelektualną. W: (red.) Głodkowska, Joanna, Giryński, Andrzej. Seksualność osób z niepetnosprawnościa intelektualna - uwalnianie od schematów i upokorzeń. Warszawa: APS im. Marii Grzegorzewskiej, s. $9-23$

Glaser, Barney, Strauss, Anselm. 2009. Odkrywanie teorii ugruntowanej. Tłum. M. Gorzko. Kraków: Zakład Wydawniczy NOMOS.

Goffman, Erving. 2005. Piętno. Rozważania o zranionej tożsamości. Tłum. A. Dzierżyńska, J. Tokarska-Bakir. Gdańsk: GWP.

Gorzko, Marek. 2008. Procedury i emergencja. O metodologii klasycznych odmian teorii ugruntowanej. Szczecin: Wydawnictwo Naukowe Uniwersytetu Szczecińskiego.

Izdebski, Zbigniew, Bartosik, Grzegorz, Kaliwoda, Anna. 2002. Zachowanie seksualne i wiedza na temat HIVIAIDS w grupie kobiet świadczących ustugi seksualne. Raport TNS OBOP http://www.aids.gov.pl/badania spoleczne/228; dostęp: 29.09.2014.

Izdebski, Zbigniew. 2006. Ryzykowna dekada. Seksualność Polaków w dobie HIV/AIDS. Studium porównawcze 1997-2001-2005. Zielona Góra: Oficyna Wydawnicza Uniwersytetu Zielonogórskiego.

- - -. 2012. Seksualność Polaków na początku XXI wieku. Studium badawcze. Kraków: Wydawnictwo Uniwersytetu Jagiellońskiego.

Jeffreys, Sheila. 2001. Legalizacja prostytucji nie jest rozwiąaniem. W: "Prawo i Płeć" 1, s. 34-40

Karpiński, Marek. 1997. Najstarszy zawód świata. Historia prostytucji. Berkshire: Lemur.

Konecki, Krzysztof. 2000. Studia z metodologii badań jakościowych. Teoria ugruntowana. Warszawa: PWN. 
Ostrowska, Antonina. 1997. Postawy społeczeństwa polskiego w stosunku do osób niepetnosprawnych. W: (red.) Gustavsson Anders, Zakrzewska-Manterys Elżbieta. Upośledzenie w spotecznym zwierciadle. Warszawa: Wydawnictwo "Żak", s. 75-95.

- - -. 2007. Seksualność osób niepetnosprawnych. W: (red.) Ostrowska, Antonina. O seksualności osób niepetnosprawnych. Warszawa: Wydawnictwo "Garmond", s. 11-24.

Roberts, Nickie. 1997. Dziwki w historii: prostytucja w społeczeństwie zachodnim. Tłum. L. Engelking. Warszawa: Volumen.

Rossiaud, Jacques. 1997. Prostytucja w średniowieczu. Tłum. P. Salwa. Warszawa: Volumen.

Sanders, Teela. 2008. Male Sexual Scripts: Intimacy, Sexuality and Pleasure in the Purchase of Commercial Sex. W: „Sociology" 42, s. 400-417.

Silverberg, Cory, Odette, Fran, Kaufman, Miriam. 2013. Petnosprawni! Uniwersalny przewodnik po seksie dla tych, którzy żyja z niepetnosprawnościa, chronicznym bólem i chorobą. Tłum. J. Gładysek. Warszawa: Wydawnictwo Czarna Owca.

Ślęzak, Izabela. 2016. Praca kobiet świadczących usługi seksualne w agencjach towarzyskich. Łódź: Wydawnictwo Uniwersytetu Łódzkiego.

- - -. 2014a. Kolektywny wymiar budowania zaangażowania w pracę seksualna kobiet świadczących ustugi seksualne w agencjach towarzyskich. W: „Przegląd Socjologii Jakościowej” 10(4), s. 56-79.

- - -. 2014b. Od procederu do pracy - oblicza prostytucji w ujęciach naukowych i społecznej percepcji. W: (red.) Warzywoda-Kruszyńska, Wielisława. Społeczeństwo, edukacja, praca, Łódź: Wydawnictwo Uniwersytetu Łódzkiego, s. 49-72.

Tederko, Piotr. 2007. Zaburzenia seksualne u osób po urazie rdzenia kręgowego. W: (red.) Ostrowska, Antonina. O seksualności osób niepetnosprawnych. Warszawa: Wydawnictwo "Garmond", s. 116-130. 